\title{
Using dissolved oxygen concentrations to determine mixed layer depths in the Bellingshausen Sea
}

\author{
K. Castro-Morales ${ }^{1,2}$ and J. Kaiser ${ }^{1}$ \\ ${ }^{1}$ University of East Anglia, Norwich, UK \\ ${ }^{2}$ Alfred Wegener Institute for Polar and Marine Research, Bremerhaven, Germany \\ Correspondence to: K. Castro-Morales (karel.castro-morales@awi.de)
}

Received: 6 June 2011 - Published in Ocean Sci. Discuss.: 23 June 2011

Revised: 13 December 2011 - Accepted: 15 December 2011 - Published: 4 January 2012

\begin{abstract}
Concentrations of oxygen $\left(\mathrm{O}_{2}\right)$ and other dissolved gases in the oceanic mixed layer are often used to calculate air-sea gas exchange fluxes. The mixed layer depth $\left(z_{\text {mix }}\right)$ may be defined using criteria based on temperature or density differences to a reference depth near the ocean surface. However, temperature criteria fail in regions with strong haloclines such as the Southern Ocean where heat, freshwater and momentum fluxes interact to establish mixed layers. Moreover, the time scales of airsea exchange differ for gases and heat, so that $z_{\text {mix }}$ defined using oxygen may be different than $z_{\text {mix }}$ defined using temperature or density. Here, we propose to define an $\mathrm{O}_{2}$-based mixed layer depth, $z_{\text {mix }}\left(\mathrm{O}_{2}\right)$, as the depth where the relative difference between the $\mathrm{O}_{2}$ concentration and a reference value at a depth equivalent to $10 \mathrm{dbar}$ equals $0.5 \%$. This definition was established by analysis of $\mathrm{O}_{2}$ profiles from the Bellingshausen Sea (west of the Antarctic Peninsula) and corroborated by visual inspection. Comparisons of $z_{\text {mix }}\left(\mathrm{O}_{2}\right)$ with $z_{\text {mix }}$ based on potential temperature differences, i.e., $z_{\operatorname{mix}}\left(0.2^{\circ} \mathrm{C}\right)$ and $z_{\operatorname{mix}}\left(0.5^{\circ} \mathrm{C}\right)$, and potential density differences, i.e., $z_{\text {mix }}\left(0.03 \mathrm{~kg} \mathrm{~m}^{-3}\right)$ and $z_{\text {mix }}\left(0.125 \mathrm{~kg} \mathrm{~m}^{-3}\right)$, showed that $z_{\text {mix }}\left(\mathrm{O}_{2}\right)$ closely follows $z_{\text {mix }}\left(0.03 \mathrm{~kg} \mathrm{~m}^{-3}\right)$. Further comparisons with published $z_{\text {mix }}$ climatologies and $z_{\text {mix }}$ derived from World Ocean Atlas 2005 data were also performed. To establish $z_{\text {mix }}$ for use with biological production estimates in the absence of $\mathrm{O}_{2}$ profiles, we suggest using $z_{\text {mix }}\left(0.03 \mathrm{~kg} \mathrm{~m}^{-3}\right)$, which is also the basis for the climatology by de Boyer Montégut et al. (2004).
\end{abstract}

\section{Introduction}

The oceanic mixed layer is the top part of the water column where temperature and solute concentrations are vertically homogeneous due to wind-driven turbulent mixing (Lukas and Lindstrom, 1991; Brainerd and Gregg, 1995). This is an important region that directly interacts with the atmosphere through exchange of momentum, heat, moisture, gases and aerosols (Dong et al., 2008). The mixed layer depth $\left(z_{\operatorname{mix}}\right)$ defines the bottom boundary of the mixed layer and separates it from the pycnocline. Mixing between waters in the mixed layer and waters below determines the ventilation of the ocean interior and influences the large-scale circulation (Cisewski et al., 2008; Le Quéré et al., 2003).

The biological response to physical forcing is not always immediate. Likewise, changes in light or micronutrient levels may stimulate rapid biological changes, but are not necessarily reflected in changes of physical properties of the surface ocean. Therefore, physical and biogeochemical tracers cannot be expected a priori to show the same scales of variability. For example, heat exchange is generally faster than gas exchange (Fairall et al., 2000). Mixed layer depths could also be different, depending on whether they refer to temperature or to gases. Moreover, different gases respond at different rates to wind forcing, depending on their solubility, with less soluble gases (e.g., $\mathrm{N}_{2}$, Ar or $\mathrm{O}_{2}$ ) responding more quickly. Therefore, for air-sea gas exchange studies and related topics such as biological production estimates from $\mathrm{O}_{2} / \mathrm{Ar}$ ratio and oxygen triple isotopes (Kaiser et al., 2005; Reuer et al., 2007), it is important to have a proper representation of $z_{\text {mix }}$ in terms of gas fluxes.

In the Southern Ocean, a strong coupling exists between atmosphere and surface waters due to the lack of physical barriers for the eastward flowing Antarctic Circumpolar Current, leading to pronounced meridional gradients and defined frontal regions. In this marine ecosystem, physical processes are an important driver for biogeochemical processes, such as biological production in the surface ocean (Rintoul and Trull, 2001; Smith et al., 2008). The Southern Ocean accounts for a significant fraction of oceanic $\mathrm{CO}_{2}$ uptake (Sarmiento et al., 1998; Sarmiento and Le Quéré, 1996). In particular, 
Antarctic shelf waters act as a strong sink of atmospheric $\mathrm{CO}_{2}$ due to high biological productivity, intense winds and high deep-water ventilation rates (Arrigo et al., 2008).

Previous definitions of $z_{\text {mix }}$ in the Southern Ocean have used criteria based on physical properties of the water column, such as potential temperature or density (Cisewski et al., 2008; Dong et al., 2008; Gordon and Huber, 1990; Rintoul and Trull, 2001; Verdy et al., 2007). However, temperature and salinity do not always show the same stratification, leading to water column structures such as temperature inversions (i.e., abrupt changes in the temperature profile due to intrusions of water masses), barrier layers (as a result of temperature inversions and at locations where the halocline is shallower than the thermocline) and density-compensated profiles (de Boyer Montégut et al., 2004; Rintoul and Trull, 2001). These structures can develop frequently in high latitude coastal areas, such as the western Antarctic Peninsula (WAP), due to the combined effect of shelf bathymetry and sea-ice dynamics (Ducklow et al., 2006; Williams et al., 2008). In the WAP region, little temperature stratification occurs and the density distribution is dominated by the influence of ice melt on salinity (de Boyer Montégut et al., 2004; Dong et al., 2008).

Most definitions of $z_{\text {mix }}$ can be classified into two groups: (a) gradient-based criteria, where $z_{\text {mix }}$ is the depth where the vertical gradient of an oceanic property reaches a threshold value (Lukas and Lindstrom, 1991) and (b) difference-based criteria, where $z_{\text {mix }}$ is the depth where an oceanic property has changed by a certain amount from a near-surface reference value (Levitus, 1982).

Previous studies have found that well-resolved vertical profiles are necessary to use successfully gradient-based criteria (Brainerd and Gregg, 1995; Cisewski et al., 2008). For example, Dong et al. (2008) concluded that the presence of anomalous spikes and perturbations in profiles from ARGO floats could lead to erroneously low $z_{\text {mix }}$. The authors found that gradient-based $z_{\text {mix }}$ deviates as much as $100 \mathrm{~m}$ from difference-based $z_{\text {mix }}$. This was mainly due to limited resolution and noise of the temperature and conductivity sensors of the floats. Difference-based criteria perform better in such circumstances as well as in regions with temperature inversions or weak upper water column stratification. However, simulations using an ocean general circulation model have shown that a latitude-dependent difference criterion may actually give the best results (Noh and Lee, 2008).

Other $z_{\text {mix }}$ definitions include curvature of temperature or density profiles (Lorbacher et al., 2006), combinations of physical criteria (Holte and Talley, 2009), optical measurements (Zawada et al., 2005) and split and merge methods (Thomson and Fine, 2003). These criteria require more complex numerical methods or additional measurements to determine $z_{\text {mix }}$.

$\mathrm{O}_{2}$ is used as a tracer for water masses, biological activity and air-sea exchange (Jenkins and Jacobs, 2008; Körtzinger et al., 2008; Reuer et al., 2007). Dissolved $\mathrm{O}_{2}$ responds

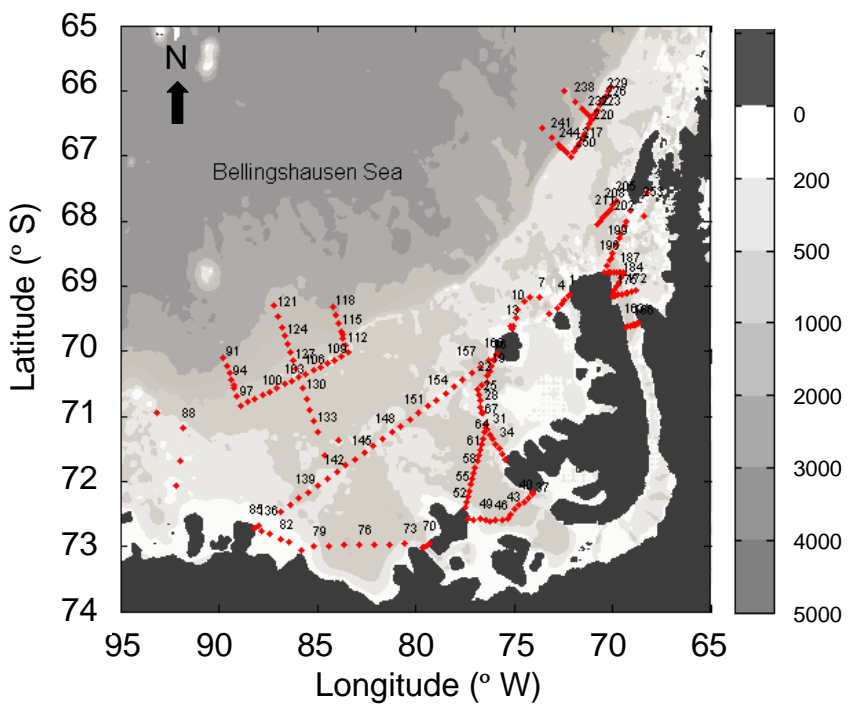

Fig. 1. CTD stations occupied by RRS James Clark Ross cruise JR165 in the Bellingshausen Sea from late summer to early autumn 2007 (3 March to 9 April 2007). Labels indicate station numbers.

to the same physical processes (e.g., vertical mixing, horizontal advection, air-sea exchange) as heat. However, since the response of $\mathrm{O}_{2}$ solubility to changes in temperature and salinity is not linear and immediate, $z_{\text {mix }}$ defined solely by differences in potential density does not fully describe the properties of the water column in terms of dissolved $\mathrm{O}_{2}$ and temperature-associated solubility changes. $\mathrm{O}_{2}$ also depends on biology and therefore gives a more complete picture of all relevant processes.

It makes sense to define $z_{\text {mix }}$ using $\mathrm{O}_{2}$ concentrations in the context of net and gross biological production estimates, where $z_{\text {mix }}$ is used to calculate weighted-average gas exchange coefficients (Reuer et al., 2007). In the Bellingshausen Sea, the main factors controlling the initiation and maintenance of the high algal biomass are physical dynamics, iron and light availability, which are driven by the mixed layer depth variability. According to Boyd et al. (1995), high chlorophyll concentrations in the upper water column of the Bellingshausen Sea remained unchanged for about 25 days during austral summer.

Here, we propose to define $z_{\text {mix }}$ using a criterion based on the relative difference between $\mathrm{O}_{2}$ concentrations and a reference value at a depth equivalent to $10 \mathrm{dbar}$. $\mathrm{O}_{2}$ is commonly measured during hydrocasts and modern electrochemical or optical $\mathrm{O}_{2}$ sensors give sufficiently stable results for establishing $z_{\text {mix }}$. The corresponding $z_{\text {mix }}\left(\mathrm{O}_{2}\right)$ was first obtained through visual inspection of vertical $\mathrm{O}_{2}$ profiles in the Bellingshausen Sea. We summarise the different criteria used to define $z_{\text {mix }}$ in global climatologies and in climatologies specific to the Southern Ocean (Table 1) and compare them with $z_{\text {mix }}\left(\mathrm{O}_{2}\right)$. Climatologies may be useful where no CTD$\mathrm{O}_{2}$ data are available to determine $z_{\text {mix }}\left(\mathrm{O}_{2}\right)$. 
Table 1. Climatologies used in this work to compare with the mixed layer depths extracted from $\mathrm{O}_{2}$ profiles.

\begin{tabular}{|c|c|c|c|c|c|c|c|}
\hline Abbreviation & Authors & Description & Data source $^{2}$ & Profiles & Resolution & Criteria & $\begin{array}{l}\text { Reference } \\
\text { depth }\end{array}$ \\
\hline ML97 & $\begin{array}{l}\text { Monterey and } \\
\text { Levitus (1997) }\end{array}$ & $z_{\text {mix }}$ climatology & $\begin{array}{c}\text { WOA94 } \\
(1900-1992)\end{array}$ & $\begin{array}{l}\text { averaged, } \\
\text { interpolated }\end{array}$ & $\begin{array}{l}1^{\circ} \times 1^{\circ} \\
\text { monthly }\end{array}$ & $\begin{array}{c}\Delta \sigma_{\theta}=0.125 \mathrm{~kg} \mathrm{~m}^{-3} \\
\text { and } \Delta \theta=0.5^{\circ} \mathrm{C}\end{array}$ & $0 \mathrm{~m}$ \\
\hline K03 & $\begin{array}{l}\text { Kara et al. } \\
(2003)\end{array}$ & $z_{\operatorname{mix}}$ climatology & $\begin{array}{c}\text { WOA94 } \\
(1900-1992)\end{array}$ & $\begin{array}{l}\text { averaged, } \\
\text { interpolated }\end{array}$ & $\begin{array}{l}1^{\circ} \times 1^{\circ} \\
\text { monthly }\end{array}$ & $\begin{array}{c}\Delta \sigma_{\theta} \text { corresponding } \\
\text { to } \Delta \theta=0.8^{\circ} \mathrm{C}\end{array}$ & $0 \mathrm{~m}$ \\
\hline BM04 & $\begin{array}{l}\text { de Boyer Montégut } \\
\text { et al. (2004) and } \\
\text { LOCEAN-IPSL }^{1} \\
(2008)\end{array}$ & $z_{\text {mix }}$ climatology & $\begin{array}{c}\text { NODC/WOCE/Argo } \\
(1941-2008)\end{array}$ & individual & $\begin{array}{l}2^{\circ} \times 2^{\circ} \\
\text { monthly }\end{array}$ & $\begin{array}{c}\Delta \sigma_{\theta}=0.03 \mathrm{~kg} \mathrm{~m}^{-3} \\
\text { and } \Delta \theta=0.2^{\circ} \mathrm{C}\end{array}$ & $10 \mathrm{~m}$ \\
\hline WOA05- $\sigma_{\theta}$ & This work & $\begin{array}{c}T \text { and } S \\
\text { climatology }\end{array}$ & $\begin{array}{c}\text { WOA } \\
(1965-2005)\end{array}$ & $\begin{array}{l}\text { averaged, } \\
\text { interpolated }\end{array}$ & $\begin{array}{l}1^{\circ} \times 1^{\circ} \\
\text { monthly }\end{array}$ & $\Delta \sigma_{\theta}=0.03 \mathrm{~kg} \mathrm{~m}^{-3}$ & $10 \mathrm{~m}$ \\
\hline WOA05- $\mathrm{O}_{2}$ & This work & $\begin{array}{c}c\left(\mathrm{O}_{2}\right) \\
\text { climatology }\end{array}$ & $\begin{array}{c}\text { WOA } \\
(1965-2005)\end{array}$ & $\begin{array}{c}\text { averaged, } \\
\text { interpolated }\end{array}$ & $\begin{array}{l}1^{\circ} \times 1^{\circ} \\
\text { monthly }\end{array}$ & $\Delta s\left(\mathrm{O}_{2}=0.5 \%\right)$ & $10 \mathrm{~m}$ \\
\hline
\end{tabular}

${ }^{1}$ Laboratoire d'Océanographie et de Climatologie par l'Expérimentation et l'Analyse Numérique - Institut Pierre Simon Laplace (updated version from the previously published version (de Boyer Montégut et al., 2004).

2 WOA: World Ocean Atlas; NODC: National Oceanographic Data Center; WOCE: World Ocean Circulation Experiment.

\section{Methods}

\subsection{CTD data acquisition}

Vertical profiles of temperature $(\theta)$, salinity $(S)$ and dissolved $\mathrm{O}_{2}$ concentration $\left(c\left(\mathrm{O}_{2}\right)\right)$ were obtained at 253 hydrographic stations in the Bellingshausen Sea (RRS James Clark Ross cruise JR165) (Fig. 1). The cruise took part within the framework of the ACES-FOCAS project (Antarctic Climate and the Earth System-Forcing from the Oceans, Clouds, Atmosphere and Sea-ice) of the British Antarctic Survey.

The Bellingshausen Sea is situated to the west of the Antarctic Peninsula between $75^{\circ} \mathrm{W}$ and $90^{\circ} \mathrm{W}$ and is a transition region between continental shelf, shelf breaks and the open ocean. The sampling period consisted of 38 days between 3 March and 9 April 2007, which represents the seasonal shift from late summer to early autumn. The hydrographic profiles were taken with a Sea-Bird $911+$ CTD package mounted on a rosette with 12 ten-litre Niskin bottles for the collection of water samples.

The CTD conductivity sensor was calibrated on board against discrete samples analysed with a Guildline Autosal 8400B. A high-precision reversing thermometer sensor (Sea-Bird SBE35) and two $\mathrm{O}_{2}$ sensors $\left(\mathrm{CTD}-\mathrm{O}_{2} ;\right.$ Sea-Bird SBE43) were also mounted on the rosette. The $\mathrm{O}_{2}$ sensors responded less rapidly than the other CTD sensors. Sensor lags of $8 \mathrm{~s}$ and $9 \mathrm{~s}$ were established for the two sensors by finding the lag time that minimised the mean and root mean square differences between the downcast and upcast. Plots of downcast and upcast alignment were used as visual check for the quality of the correction. $\mathrm{O}_{2}$ profiles in deep CTD casts $>1000 \mathrm{~m}$ were reported to be affected by pressure hysteresis (Sea-Bird Electronics, 2010). However, lit- tle hysteresis was observed in our profiles, since only 38 of them reached depths greater than $1000 \mathrm{~m}$. A small correction had to be applied to the pressure sensor, which amounted to the following values: CTDs 000-021: $-1.21 \mathrm{dbar}$; CTDs 022-085: -0.71 dbar; CTDs 086-164: -1.05 dbar and CTDs 165-253: -0.80 dbar.

One of the $\mathrm{O}_{2}$ sensors proved to be more stable and was selected for calibration. The $\mathrm{O}_{2}$ discrete samples were analysed on board using whole-bottle Winkler titration (Dickson, 1996) with photometric end-point detection. A total of 276 titrations were performed with a repeatability of $0.29 \mu \mathrm{mol} \mathrm{kg}{ }^{-1}(0.1 \%)$ based on 76 duplicate samples. The average difference between the non-calibrated CTD- $\mathrm{O}_{2}$ and Winkler data was $(3.9 \pm 3.1) \mu \mathrm{mol} \mathrm{kg}{ }^{-1}$.

Notwithstanding our calibration efforts, the $\mathrm{O}_{2}$-based mixed layer depth criterion proposed here actually does not require of calibrated profiles as it is based on relative differences in oxygen concentration, so that sensor gain biases cancel out.

The CTD data were binned into 2 dbar-depth intervals starting from $1 \mathrm{dbar}\left(=10^{4} \mathrm{~Pa}\right.$, or about $\left.1 \mathrm{~m}\right)$ to the maximum depth for each station. For determining $z_{\text {mix }}$ using difference criteria, the sensor precision is more important than the absolute accuracy. The sensor precision was estimated from the relative standard deviation of the $\mathrm{CTD}-\mathrm{O}_{2}$ readings within 2 dbar-bins in the mixed layer, which was found to be $(0.4 \pm 0.3) \%$, on average. From a total of 253 CTD profiles, only two were discarded due to sensor problems (stations 27 and 43). Sensor noise affected our measurements only in the top 5 dbar of most CTD stations. 


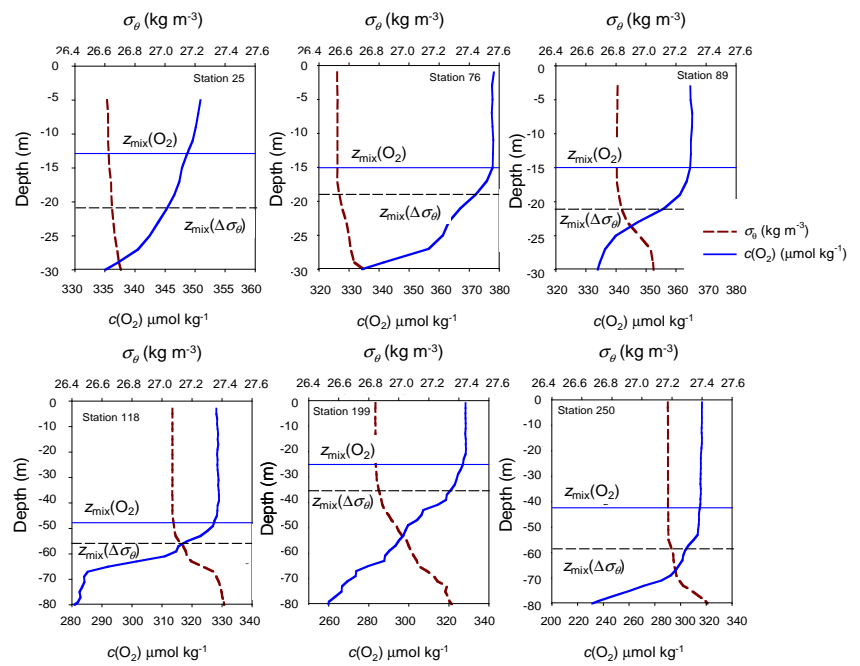

Fig. 2. Vertical profiles of $\mathrm{O}_{2}$ concentration, $c\left(\mathrm{O}_{2}\right)$, and potential density $\left(\sigma_{\theta}\right)$. Horizontal lines indicate the location of the objective $z_{\text {mix }}\left(\mathrm{O}_{2}\right)$ and $z_{\text {mix }}\left(0.03 \mathrm{~kg} \mathrm{~m}^{-3}\right)$.

\subsection{Definition of the $z_{\text {mix }}\left(\mathrm{O}_{2}\right)$ criterion}

To define a $z_{\text {mix }}$ criterion based on $\mathrm{O}_{2}$, all 253 CTD profiles were initially inspected visually. Some examples of typical profiles encountered during the survey are depicted in Fig. 2. Subjective (i.e., visually determined) $z_{\operatorname{mix}}$ was then compared to objective (numerically determined) $z_{\text {mix }}$ to identify a suitable $\mathrm{O}_{2}$ criterion for $z_{\text {mix }}$. The latter consisted in testing three threshold criteria $(0.1 \%, 0.5 \%$ and $1.0 \%)$ with respect to the near-surface $(\approx 1-3 \mathrm{dbar})$ and $10 \mathrm{dbar}$ concentrations. The near-surface value was identified as the lowest depth with a $c\left(\mathrm{O}_{2}\right)$ measurement. The different thresholds were applied objectively and the result was compared to the subjective mixed layer depth (Fig. 3).

Compared to the objective $z_{\mathrm{mix}}$ values, our results suggest that the subjective $z_{\text {mix }}$ is deeper, when using a $0.1 \%$ threshold, by $(8.7 \pm 8.0) \mathrm{m}$ and $(6.0 \pm 7.6) \mathrm{m}$ with respect to the near-surface and $10 \mathrm{dbar}$ values, respectively. For a $1.0 \%$ threshold, the subjective $z_{\text {mix }}$ is only slightly shallower than the objective $z_{\text {mix }}$ by $(0.7 \pm 5.0) \mathrm{m}$ and $(2.3 \pm 3.5) \mathrm{m}$ when using near-surface and $10 \mathrm{dbar}$ values for reference, respectively. For the threshold criterion of $0.5 \%$ and the nearsurface value as reference, the difference to the subjective result was on average $(3.1 \pm 6.1) \mathrm{m}$; for the $10 \mathrm{dbar}$ value as reference, the difference was $(0.9 \pm 4.6) \mathrm{m}$ (Fig. 3).

Although the results from $1.0 \%$ difference with respect to the near-surface value and the $0.5 \%$ difference with respect to the $10 \mathrm{dbar}$ are in close agreement, our preferred criterion was the latter for two reasons: In agreement to Brainerd and Gregg (1995), the 10 dbar reference depth avoids sensor noise in the surface water due to the effect of ship motion and sensor stabilization. The reference depth of $10 \mathrm{dbar}$ was also chosen for consistency with other studies and to allow

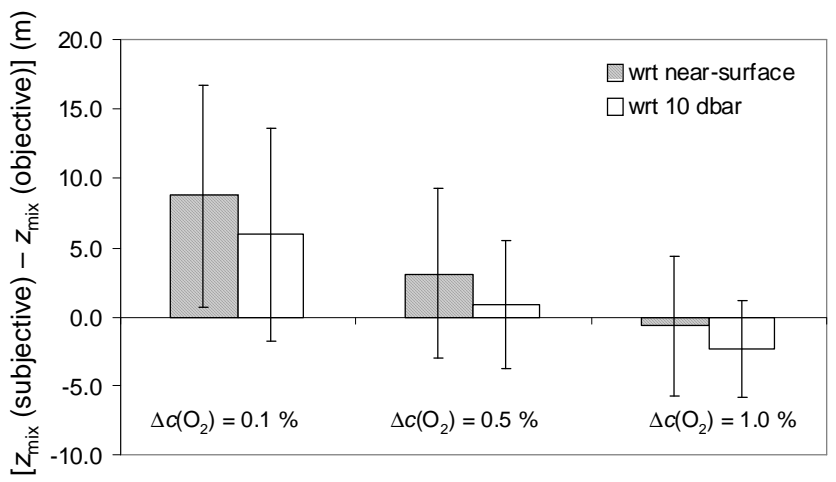

Fig. 3. Mean difference between $z_{\text {mix }}$ obtained subjectively (by visual inspection) and $z_{\text {mix }}\left(\mathrm{O}_{2}\right)$ obtained using three threshold criteria with two different reference depths: (1) $0.1 \%$, (2) $0.5 \%$ and (3) $1.0 \%$, with respect to $c\left(\mathrm{O}_{2}\right)$ in near-surface water $(\approx 2 \mathrm{dbar})$ and at $10 \mathrm{dbar}$.

comparison of our results to climatological data that use the same reference depth. Using this reference depth means that the minimum $z_{\text {mix }}$ possible is $10 \mathrm{dbar}$.

\subsection{Comparison with density- and temperature-based $z_{\text {mix }}$ and climatologies}

To test our new $z_{\text {mix }}$ criterion, we first compared it with conventional $z_{\text {mix }}$ definitions based on temperature and potential density. These criteria were adopted from three widely used $z_{\text {mix }}$ climatologies (Table 1) and applied to the 251 CTD profiles of this study. In a second step, we compared $z_{\text {mix }}\left(\mathrm{O}_{2}\right)$ to the climatological $z_{\text {mix }}$ values, interpolated according to location and time of year.

Climatologies represent binned and averaged monthly fields. The $z_{\text {mix }}$ climatologies by Monterey and Levitus (1997); Kara et al. (2003) and de Boyer Montégut et al. (2004) (abbreviated as ML97, K03 and BM04) are widely used in oceanographic studies. We obtained the climatological data from http://www.esrl.noaa.gov/psd/ data/gridded/data.nodc.woa94.html, http://www7320.nrlssc. navy.mil/nmld/nmld.html and http://www.locean-ipsl.upmc. fr $/ \sim$ cdblod/mld.html (de Boyer Montégut et al., 2004; Kara et al., 2003; Monterey and Levitus, 1997). ML97 and K03 are based on data from the World Ocean Atlas 1994 (WOA94). BM04 is based on individual CTD profiles obtained from the World Ocean Circulation Experiment (WOCE) and the National Oceanographic Center (NODC) and the latest update includes profiles from Argo floats. The BM04 climatology is obtained by an ordinary kriging of the data distributed in $2^{\circ}$ boxes, with a prediction limited to $1000 \mathrm{~km}$ radius. No value is assigned if there are less than 5 data points in a grid box. BM04 includes profiles from mechanical bathythermograph (MBT), expendable bathythermograph (XBT), CTD hydrocasts and profiling floats, providing a range of vertical resolutions from $2.3 \mathrm{~m}$ (CTD) to 


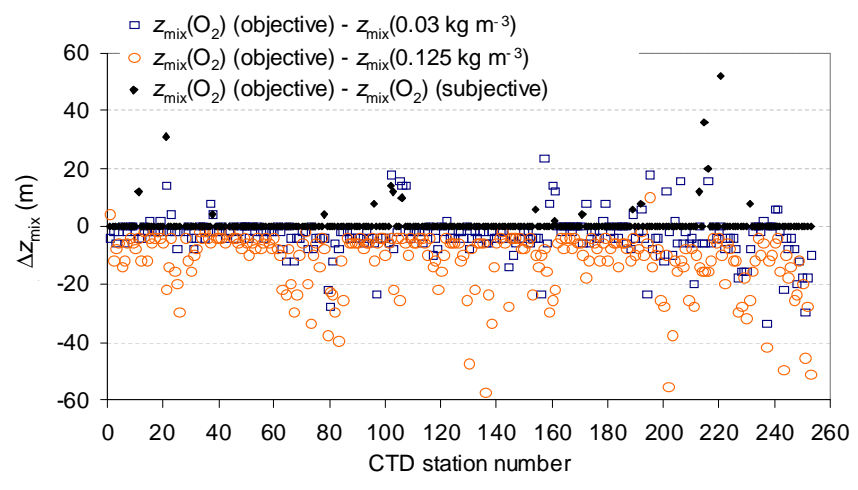

Fig. 4. Difference of objective $\mathrm{O}_{2}$-based $z_{\text {mix }}$ to subjective $\mathrm{O}_{2}$ based $z_{\text {mix }}$ and $z_{\text {mix }}$ based on two potential density threshold criteria applied to the CTD profiles in the Bellingshausen Sea.

$19.5 \mathrm{~m}$ (XBT). The ML97 and K03 climatologies consider a smaller radius of influence $(771 \mathrm{~km})$. However, interpolation of data and smoothing were performed within that radius leading to larger uncertainties in the data.

Based on ML97 and BM04, the following criteria were chosen to define $z_{\text {mix }}$ based on potential temperature $(\theta)$ and potential density $\left(\sigma_{\theta}\right)$ differences: $\Delta \theta=0.5^{\circ} \mathrm{C}$ and $\Delta \sigma_{\theta}=0.125 \mathrm{~kg} \mathrm{~m}^{-3}$ with respect to the surface value (ML97); $\Delta \theta=0.2^{\circ} \mathrm{C}$ and $\Delta \sigma_{\theta}=0.03 \mathrm{~kg} \mathrm{~m}^{-3}$ with respect to the $10 \mathrm{dbar}$ value (BM04). These criteria were applied to the same $251 \mathrm{CTD}$ profiles used to determine $z_{\text {mix }}\left(\mathrm{O}_{2}\right)$. In addition, $z_{\text {mix }}\left(\mathrm{O}_{2}\right)$ was compared with the maximum curvaturebased $z_{\text {mix }}$ algorithm of Lorbacher et al. (2006) (abbreviated as L06) using temperature and potential density. Finally, we also compared our observations with a $z_{\text {mix }}$ obtained after a mixed layer criterion based on the $95 \% \mathrm{O}_{2}$ saturation (Talley, 1999; Holte and Talley, 2009).

The $z_{\text {mix }}$ values from ML97, K03 and BM04 were also directly compared with $z_{\text {mix }}\left(\mathrm{O}_{2}\right)$ after linear interpolation to the same month, latitude and longitude. Since these climatologies suffer from poor data coverage in the Southern Ocean, particularly south of $30^{\circ} \mathrm{S}$ in the Antarctic coastal zone, we planned to use a dedicated Southern Ocean $z_{\text {mix }}$ climatology based on $\sigma_{\theta}$ differences derived from Argo float profiles used for comparison (Dong et al., 2008). However, it turned out that this climatology did not contain any data in the region of study and could therefore not be used.

To further test the $z_{\text {mix }}\left(\mathrm{O}_{2}\right)$ criterion, we applied the $\Delta \sigma_{\theta}=0.03 \mathrm{~kg} \mathrm{~m}^{-3}$ criterion to density profiles calculated from $1^{\circ}$ by $1^{\circ}$-temperature and salinity climatology in World Ocean Atlas 2005 (WOA05; http://www.nodc.noaa. gov/OC5/WOA05/woa05data.html; (Antonov et al., 2006; Locarnini et al., 2006). Then, the $z_{\text {mix }}\left(\mathrm{O}_{2}\right)$ criterion was applied to the $\mathrm{O}_{2}$ data in WOA05 (Garcia et al., 2006). WOA05 uses the same standard depths (i.e., 0, 10, 20, 30, 50, 75, $100,125,150,200,250,300,400,500,600,700,800,900$, $1000 \mathrm{~m}$ ) and interpolation method for temperature, salinity

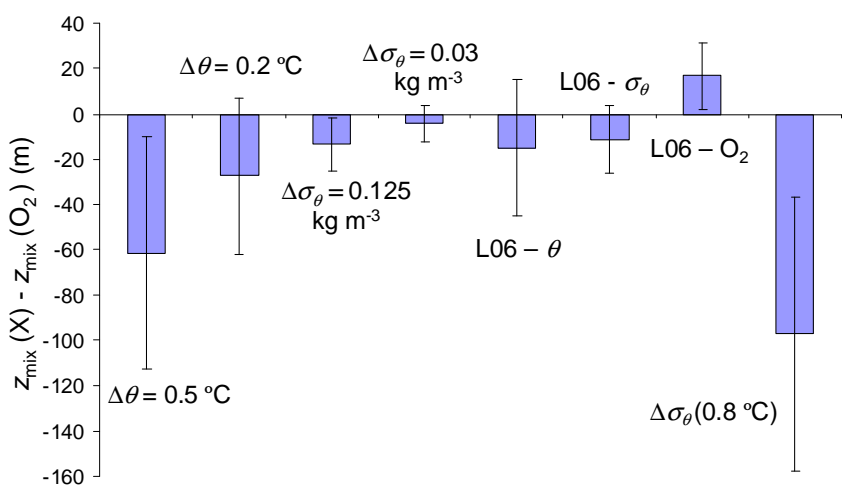

Fig. 5. Mean difference between $z_{\text {mix }}$ based on potential temperature or density differences or oxygen saturation state $\left(z_{\operatorname{mix}}(\mathrm{X})\right)$ to $z_{\text {mix }}\left(\mathrm{O}_{2}\right)$. L06 is the algorithm used by Lorbacher et al. (2006) to define $z_{\text {mix }}$ based on potential temperature (L06- $\theta$ ) and potential density $\left(\mathrm{L} 06-\sigma_{\theta}\right)$. The $\Delta \sigma_{\theta}\left(0.8^{\circ} \mathrm{C}\right)$ criterion is based on the difference in density given by a temperature difference of $0.8^{\circ} \mathrm{C}$.

and oxygen. The $\mathrm{O}_{2}$ data only comprise results obtained by Winkler titration.

\section{Results}

\subsection{Comparison between $z_{\text {mix }}\left(\mathrm{O}_{2}\right)$ from subjective and objective analysis}

$z_{\text {mix }}\left(\mathrm{O}_{2}\right)$ obtained by subjective visual inspection and by using objective numerical analysis agreed to within $1 \mathrm{dbar}$ for 235 out of 251 stations. For the remaining 16 stations, the objective $z_{\text {mix }}\left(\mathrm{O}_{2}\right)$ value was on average $(1 \pm 5)$ dbar shallower than its subjective counterpart (Fig. 4). This small discrepancy was caused by the presence of low oxygenated subsurface waters (i.e., Winter Water) that created a weak upper oxycline. The visual inspection disregarded this top oxycline and $z_{\text {mix }}\left(\mathrm{O}_{2}\right)$ was defined according to the deeper and more pronounced seasonal oxycline. In the following, the objective result is used for $z_{\text {mix }}\left(\mathrm{O}_{2}\right)$.

\subsection{Comparison between $z_{\text {mix }}\left(\mathrm{O}_{2}\right)$ and $z_{\text {mix }}$ based on $\theta$ and $\sigma_{\theta}$ differences}

The $z_{\text {mix }}\left(\mathrm{O}_{2}\right)$ criterion appears to better reflect the $\mathrm{O}_{2}$ distribution in the mixed layer, compared to the $z_{\text {mix }}\left(0.03 \mathrm{~kg} \mathrm{~m}^{-3}\right)$ criterion. This is illustrated by six typical profiles (Fig. 2). Vertical profiles for stations 25, 76, 89, 188, 199 and 250, show $z_{\text {mix }}\left(0.03 \mathrm{~kg} \mathrm{~m}^{-3}\right)$ lying in the oxycline region, deeper than $z_{\text {mix }}\left(\mathrm{O}_{2}\right)$. As a consequence, the $\mathrm{O}_{2}$ concentration is lower at $z_{\text {mix }}\left(0.03 \mathrm{~kg} \mathrm{~m}^{-3}\right)$ than at $z_{\text {mix }}\left(\mathrm{O}_{2}\right)$. This difference can lead to an underestimation of the average mixed layer $\mathrm{O}_{2}$ concentration.

No significant correlation was observed between $z_{\text {mix }}\left(\mathrm{O}_{2}\right)$ and $z_{\text {mix }}$ based on $\Delta \theta=0.5^{\circ} \mathrm{C}$ (with respect to the surface value) or based on $\Delta \theta=0.2^{\circ} \mathrm{C}$ (with respect to the $10 \mathrm{dbar}$ 
value). The corresponding correlation coefficients were $r^{2}=$ 0.001 and 0.111 , respectively. $z_{\text {mix }}\left(0.5^{\circ} \mathrm{C}\right)$ was on average $(61 \pm 51)$ dbar deeper than $z_{\text {mix }}\left(\mathrm{O}_{2}\right)$, while $z_{\text {mix }}\left(0.2^{\circ} \mathrm{C}\right)$ was (27 \pm 34$)$ dbar deeper (Fig. 5). Park et al. (1998) made similar observations in the Kerguelen region of the Southern Ocean. The authors argued that the $z_{\text {mix }}\left(0.5^{\circ} \mathrm{C}\right)$ criterion gave $z_{\text {mix }}$ greater than $500 \mathrm{~m}$, compared to the actual $z_{\text {mix }}$ above $200 \mathrm{~m}$ depth. The authors also tested smaller differences of $0.05^{\circ} \mathrm{C}$ and $0.1{ }^{\circ} \mathrm{C}$. However, due to the small temperature gradient, particularly in winter, the $z_{\text {mix }}$ was still overestimated by 10 to $490 \mathrm{~m}$. This was previously observed by Lukas and Lindstrom (1991) for the equatorial Pacific Ocean, who also argued that the threshold should be based on density since the temperature profile does not fully capture the vertical stratification of the water column. In regions with daily and seasonal cycles dominated by heat flux, a temperature-based criterion may be sufficient to define mixed layer depths. However, in regions where precipitation and ice melt play an important role on water column stratification, density-based criteria are preferable (Cisewski et al., 2008; Park et al., 1998)

Comparison between $z_{\text {mix }}\left(\mathrm{O}_{2}\right)$ and $z_{\text {mix }}$ based on $\Delta \sigma_{\theta}=0.125 \mathrm{~kg} \mathrm{~m}^{-3}$ with respect to the surface value and $\Delta \sigma_{\theta}=0.03 \mathrm{~kg} \mathrm{~m}^{-3}$ with respect to the $10 \mathrm{dbar}$ value, showed a better agreement than for the solely $\theta$-based criteria. The corresponding correlation coefficients were $r^{2}=0.711$ and 0.813 , respectively. $z_{\text {mix }}\left(0.125 \mathrm{~kg} \mathrm{~m}^{-3}\right)$ was on average $(14 \pm 11)$ dbar deeper than $z_{\text {mix }}\left(\mathrm{O}_{2}\right)$, while $z_{\text {mix }}\left(0.03 \mathrm{~kg} \mathrm{~m}^{-3}\right)$ was $(4 \pm 8) \mathrm{dbar}$ deeper (Figs. 4 and 5 ). The criterion considering a temperature change of $0.8^{\circ} \mathrm{C}, \Delta \sigma_{\theta}\left(0.8^{\circ} \mathrm{C}\right)$ $=\sigma_{\theta}\left(\theta+0.8^{\circ} \mathrm{C}\right)-\sigma_{\theta}(\theta)$ with respect to the $10 \mathrm{dbar}$ value, had a poor correlation with $z_{\text {mix }}\left(\mathrm{O}_{2}\right)\left(r^{2}=0.016\right)$, and $z_{\text {mix }}\left(\Delta \sigma_{\theta}\left(0.8^{\circ} \mathrm{C}\right)\right)$ was on average $(97 \pm 61)$ dbar deeper than $z_{\text {mix }}\left(\mathrm{O}_{2}\right)$. We also confirmed the results obtained based on the $\Delta \sigma_{\theta}$ criteria visually. Objective and subjective results agreed to within $(2 \pm 6) \mathrm{dbar}$ for all criteria. It is important to note that, for fair comparison with the tested criterion, we have used the corresponding oxygen concentration at the same reference depth suggested by each criterion (i.e., surface value or the value at $10 \mathrm{~m}$ depth).

Lorbacher et al. (2006) defined $z_{\text {mix }}$ based on the first extreme curvature in the temperature or potential density profile. Compared to difference criteria, this approach has the advantage of being independent of the actual value of the variable in question. The same is true for $z_{\text {mix }}\left(\mathrm{O}_{2}\right)$, which uses a relative difference of $0.5 \%$, independent of the $\mathrm{O}_{2}$ concentration. The mixed layer depth based on temperature curvature, $z_{\text {mix }}\left(\theta^{\prime \prime}\right)$, gave $(15 \pm 30)$ dbar deeper values than $z_{\text {mix }}\left(\mathrm{O}_{2}\right) ; z_{\text {mix }}$ based on density curvature, $z_{\text {mix }}\left(\sigma_{\theta}^{\prime \prime}\right)$, gave $(11 \pm 15)$ dbar deeper values. We also tested the $\mathrm{O}_{2}$ criterion suggested here in the L06 algorithm. The mixed layer depth based on the curvature on the $\mathrm{O}_{2}$ profiles gave $(17 \pm 15) \mathrm{m}$ shallower values than $z_{\text {mix }}\left(\mathrm{O}_{2}\right)$ (Fig. 5), this is probably due to the presence of the WW intrusions observed in the upper water column.
Holte and Talley (2009) compared winter mixed layer depth defined by the $95 \% \mathrm{O}_{2}$ saturation horizon (Talley, 1999) with a $z_{\text {mix }}$ algorithm based on combinations of physical criteria. The authors found good agreement between both definitions in data from the World Ocean Atlas 2005 and Argo profiles.

Although the criterion based on $95 \% \mathrm{O}_{2}$-saturation horizon was mainly proposed to identify winter mixed layer depths, here we tested this criterion to identify summer/autumn mixed layer depth using the data from our cruise. Away from the shore (stations 90 to 163 and 197 to 253 ), the $95 \%$ saturation criterion does not give meaningful results because of the presence $\mathrm{O}_{2}$-undersaturated waters near the surface. Closer to ice shelves (stations 1 to 90 and 166 to 198), biological production is able to overcome this $\mathrm{O}_{2}$ deficit. The surface $\mathrm{O}_{2}$ saturation was $(100 \pm 4) \%$ and $z_{\text {mix }}\left(95 \% \mathrm{O}_{2}\right)$ was on average $(9 \pm 25)$ dbar shallower than $z_{\text {mix }}\left(\mathrm{O}_{2}\right)$.

\subsection{Comparison of $z_{\text {mix }}$ with climatologies}

For the following comparisons, the $z_{\text {mix }}$ data are presented in meters (rather than dbar) to maintain consistency with the $z_{\text {mix }}$ given in the climatologies. We made a direct comparison between $z_{\text {mix }}$ obtained after applying the selected criteria with the $z_{\text {mix }}$ obtained from the climatologies that make use of the same criteria. Thus, $z_{\text {mix }}\left(0.125 \mathrm{~kg} \mathrm{~m}^{-3}\right)$ was compared to $z_{\text {mix }}$ from the ML97 climatology. The same procedure was applied for $z_{\text {mix }}\left(0.03 \mathrm{~kg} \mathrm{~m}^{-3}\right)$ and $z_{\text {mix }}\left(\Delta \sigma\left(0.8^{\circ} \mathrm{C}\right)\right)$ in the BM04 and K03 climatologies, respectively. $z_{\text {mix }}$ extracted from the climatologies corresponded to the same month and geographical location of our CTDs. Due to the limited spatial coverage of the climatologies in the Southern Ocean, not all profiles had a corresponding climatological $z_{\text {mix }}$ value (170 profiles for ML97, 208 profiles for BM04 and 179 profiles for K03 all out of 251). Therefore, the comparisons below were done for the common minimum number of profiles found in the climatologies.

The ML97 and K03 climatologies have a coarse vertical resolution $(0,10,20,30,50,75,100,125,150$, 200, 250, 300, 400, 500,600, 700, 800, 900, $1000 \mathrm{~m}$ ), which puts limits on the comparison to in situ $z_{\text {mix }}$ data based on profiles with $2 \mathrm{dbar}$ resolution. For some CTD stations, climatological $z_{\text {mix }}$ was overestimated by up to $500 \mathrm{~m}$ with respect to $z_{\text {mix }}\left(\mathrm{O}_{2}\right)$. These values were disregarded for the comparison between climatological $z_{\text {mix }}$ and $z_{\text {mix }}\left(\mathrm{O}_{2}\right)$. For the BM04 climatology, the vertical resolution varies according to the source of data: PFL (Profiling Floats) data have a vertical resolution of $8.2 \mathrm{~m}$, CTD data $2.3 \mathrm{~m}$, XBT (eXpandable BathyThermograph) data $19.5 \mathrm{~m}$ and MBT (Mechanical BathyThermograph) data $9.4 \mathrm{~m}$.

Comparisons with $z_{\text {mix }}$ defined using potential density from ML97 and BM04 showed a good agreement when the same criterion was applied to our CTD profiles. We obtained for the criterion used in ML97 and BM04, an $r^{2}=0.628$ 
and $r^{2}=0.604$ (data not shown). The ML97 climatology gave $(11.9 \pm 11.6) \mathrm{m}$ shallower $z_{\text {mix }}\left(0.125 \mathrm{~kg} \mathrm{~m}^{-3}\right)$ than in the in situ data; the BM04 climatology gave $(0.7 \pm 13.5) \mathrm{m}$ shallower $z_{\text {mix }}\left(0.03 \mathrm{~kg} \mathrm{~m}^{-3}\right)$. However, $z_{\text {mix }}\left(\Delta \sigma\left(0.8^{\circ} \mathrm{C}\right)\right)$ showed poor agreement with the corresponding data from $\mathrm{K} 03\left(r^{2}=0.002\right)$, with $z_{\text {mix }}$ based on CTD profiles being (94.4 \pm 64.1$) \mathrm{m}$ deeper.

We then compared $z_{\text {mix }}\left(\mathrm{O}_{2}\right)$ (objective result) with the density-based $z_{\mathrm{mix}}$ in the BM04, ML97 and K03 climatologies. To ensure comparable results, we only used the profiles where data from all climatologies were available, so that the total number of profiles compared was 160 (Table 2). $z_{\text {mix }}\left(0.03 \mathrm{~kg} \mathrm{~m}^{-3}\right)$ from BM04 showed a positive correlation with $z_{\text {mix }}\left(\mathrm{O}_{2}\right)\left(r^{2}=0.542\right)$ and was on average $(8 \pm 10) \mathrm{m}$ deeper than $z_{\text {mix }}\left(\mathrm{O}_{2}\right) . z_{\text {mix }}\left(0.125 \mathrm{~kg} \mathrm{~m}^{-3}\right)$ from ML97 also showed a positive correlation with $z_{\text {mix }}\left(\mathrm{O}_{2}\right)\left(r^{2}=0.542\right)$, and was on average $(2 \pm 12) \mathrm{m}$ deeper than $z_{\text {mix }}\left(\mathrm{O}_{2}\right)$. No correlation was found between $z_{\text {mix }}$ from $\mathrm{K} 03$ and $z_{\text {mix }}\left(\mathrm{O}_{2}\right)$, with $z_{\text {mix }}\left(\mathrm{O}_{2}\right)$ on average $(153 \pm 300) \mathrm{m}$ deeper (Table 2$)$.

Our results show that the mixed layer depths in the BM04 and ML97 climatology are in close agreement with $z_{\text {mix }}\left(\mathrm{O}_{2}\right)$. However, the BM04 climatology showed the best coverage in the Southern Ocean, and has the advantage of having a higher vertical resolution than the other climatologies evaluated in this study.

Finally, our observations suggest that temperature-based criteria significantly overestimate $z_{\text {mix }}$ in the region of study and confirm the importance of using density to define $z_{\text {mix }}$ in this area.

\section{$3.4 z_{\text {mix }}\left(\mathrm{O}_{2}\right)$ compared with $z_{\text {mix }}$ based on WOA05 density and oxygen profiles}

The $\Delta \sigma_{\theta}=0.03 \mathrm{~kg} \mathrm{~m}^{-3}$ criterion was applied to density profiles taken from objectively analysed fields of temperature and salinity data from WOA05. We then compared the results obtained from these observations to the $z_{\text {mix }}$ using the same density criterion and the oxygen criterion both in our CTD profiles. For the WOA05 profiles we could only find matching data for 120 out of 251 CTD profiles, due to the limited spatial coverage of WOA05. A poor correlation was found for both comparisons $\left(r^{2}=0.048\right.$ and 0.043 , respectively), with $z_{\text {mix }}=0.03 \mathrm{~kg} \mathrm{~m}^{-3}$ ) based on CTD data being $(14 \pm 16) \mathrm{m}$ deeper than based on WOA05. These differences are likely due to the scarce WOA05 data in the Southern Ocean and their limited vertical resolution $(10 \mathrm{~m})$ (Table 2).

To test the $z_{\text {mix }}\left(\mathrm{O}_{2}\right)$ criterion with other $\mathrm{O}_{2}$ profiles, we used historical $\mathrm{O}_{2}$ profiles from WOA05 located at the same geographical location as our CTD stations. Our results show a positive correlation $\left(r^{2}=0.412\right)$ between $\left.z_{\text {mix }}(\text { CTD-O })_{2}\right)$

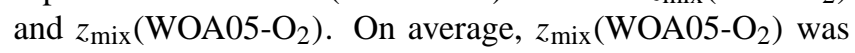
$(8 \pm 12)$ dbar shallower than $z_{\text {mix }}\left(\mathrm{CTD}-\mathrm{O}_{2}\right)$.

\section{Discussion}

Defining $z_{\text {mix }}$ based on potential temperature can lead to deeper values than $z_{\text {mix }}\left(\mathrm{O}_{2}\right)$, which is defined based on the vertical $\mathrm{O}_{2}$ distribution. The $\Delta \theta=0.5^{\circ} \mathrm{C}$ and $\Delta \theta=0.2^{\circ} \mathrm{C}$ criteria lead to $z_{\text {mix }}$ located within the oxycline. Potential density-based $z_{\text {mix }}$ values are in better agreement with $z_{\text {mix }}\left(\mathrm{O}_{2}\right)$, particularly for the $\Delta \sigma_{\theta}=0.03 \mathrm{~kg} \mathrm{~m}^{-3}$ criterion.

To explain the discrepancy between temperature and density-based $z_{\text {mix }}$, we checked for the presence of barrier layers and temperature inversions in the area of study. Barrier layers are thought to be formed by melting sea ice, although the mechanisms for the formation and destruction of barrier layers in the Southern Ocean are not well understood (de Boyer Montégut et al., 2007). Our results showed that barrier layers were present in $43 \%$ of the CTD profiles. The barrier layer thickness ranged from 2 to $93 \mathrm{~m}$. Barrier layers were also encountered below the seasonal mixed layer, but do not influence $z_{\text {mix }}\left(\mathrm{O}_{2}\right)$. The seasonal variability of the barrier layers, influenced mainly by the water column stratification, is expected to correspond to that of $z_{\text {mix }}\left(\mathrm{O}_{2}\right)$. The deepening of $z_{\text {mix }}$ during autumn and winter will lead to low- $\mathrm{O}_{2}$ waters entering the mixed layer from the barrier layer below and subsequent destruction of the barrier layer.

The fact that $z_{\text {mix }}\left(\mathrm{O}_{2}\right)$ is slightly shallower than $z_{\text {mix }}$ based on other criteria could be interpreted as an indication that $\mathrm{O}_{2}$ is a more sensitive variable to establish mixed layer depths because it responds to both physics and biology. The metabolic balance in the subsurface ocean is usually net heterotrophic, i.e., respiration exceeds production. Below the mixed layer, this leads to a general decrease of $\mathrm{O}_{2}$ concentrations with depth. In some situations, the productive euphotic zone may extend below the mixed layer, leading to a buildup of $\mathrm{O}_{2}$ below the mixed layer. In this case, our criterion of a $0.5 \%$ relative change would still work, but in the opposite direction. Only if the $\mathrm{O}_{2}$ concentration below $z_{\text {mix }}$ was the same as in the mixed layer could a situation occur when biology could obscure the mixed layer for a short period of time when production, respiration and vertical mixing were in perfect balance. Such a situation is expected to be rare and we suggest that the general applicability of the $z_{\text {mix }}\left(\mathrm{O}_{2}\right)$ criterion should be tested for the world's oceans.

Comparison between in situ $z_{\text {mix }}\left(\mathrm{O}_{2}\right)$ with $z_{\text {mix }}$ climatologies showed a good agreement for the ML97 and BM04 climatologies. BM04 has several advantages over ML97 and K03: (1) It includes Argo data up to 2008, giving better data coverage, especially in high latitudes (ML97 and K03 covered $71 \%$ and $68 \%$ of the occupied stations respectively, while BM04 83\%), (2) BM04 uses non-interpolated, nonaveraged profiles, which avoids the creation of artificially smooth profiles as in ML97 and K03; (3) ML97 and K03 have limited vertical resolution and use discrete intervals; (4) non-averaged profiles allow identification of upper water structures such as barrier layers and temperature inversions; (5) a difference-criterion based on temperature or density 
Table 2. Mean differences between $z_{\text {mix }}$ based on CTD data, $z_{\text {mix }}$ climatologies and climatological World Ocean Atlas 2005 temperature, salinity and oxygen data (WOA05).

\begin{tabular}{lrr}
\hline Difference between $z_{\text {mix }}$ based on $\mathrm{O}_{2}$ and climatological data & Mean $\pm 1 \mathrm{~s}(\mathrm{~m})$ & Number of profiles \\
\hline$z_{\text {mix }}\left(\mathrm{O}_{2}, \mathrm{CTD}\right)-z_{\text {mix }}\left(0.03 \mathrm{~kg} \mathrm{~m}^{-3}, \mathrm{BM} 04\right)$ & $-8 \pm 10$ & 160 \\
$z_{\text {mix }}\left(\mathrm{O}_{2}, \mathrm{CTD}\right)-z_{\text {mix }}\left(0.125 \mathrm{~kg} \mathrm{~m}^{-3}, \mathrm{ML} 97\right)$ & $-2 \pm 12$ & 160 \\
$z_{\text {mix }}\left(\mathrm{O}_{2}, \mathrm{CTD}\right)-z_{\text {mix }}\left(\Delta \sigma_{\theta}\left(0.8^{\circ} \mathrm{C}\right), \mathrm{K} 03\right)$ & $-153 \pm 300$ & 160 \\
$z_{\text {mix }}\left(0.03 \mathrm{~kg} \mathrm{~m}^{-3}, \mathrm{CTD}\right)-z_{\text {mix }}\left(0.03 \mathrm{~kg} \mathrm{~m}^{-3}\right.$, WOA05 $)$ & $17 \pm 17$ & 120 \\
$z_{\text {mix }}\left(\mathrm{O}_{2}, \mathrm{CTD}\right)-z_{\text {mix }}\left(\mathrm{O}_{2}\right.$, WOA05) & $8 \pm 12$ & 120 \\
\hline
\end{tabular}

with a wide threshold (such as in ML97 and K03), can lead to an overestimation of $z_{\mathrm{mix}}$. De Boyer Montégut et al. (2004) reasoned that a wider threshold might be better for averagedprofiles with a coarser and smoother resolution.

Both the ML97 and K03 temperature criteria have been applied for areas where sharp temperature stratification in the upper water column is present (i.e., tropical and sub-tropical oceanic areas). The larger temperature difference of the $\mathrm{K} 03$ criterion produces $z_{\text {mix }}$ values higher than those of ML97.

Argo float data such as used in the latest update of the BM04 climatology provide new insights for seasonal $z_{\text {mix }}$ investigations in a region where the lack of data during austral winter from direct observations collected on board research ships is considerable. Argo floats with $\mathrm{O}_{2}$ sensors have been launched since 2007, a few of them in the Southern Ocean. However, these floats are only located in deep waters and the coarse vertical resolution that the Argo profiles provide $(\approx 10.5 \mathrm{~m})$ are important limitations for detection of shallow summer $z_{\text {mix }}$ in the coastal region of the Southern Ocean. Due to this, the climatology by Dong et al. (2008) is limited to $30^{\circ} \mathrm{S}$ to $65^{\circ} \mathrm{S}$ excluding the location of the Bellingshausen Sea (i.e., $66^{\circ} \mathrm{S}$ to $74^{\circ} \mathrm{S}$ ).

$z_{\text {mix }}$ based on curvature as proposed by Lorbacher et al. (2006) showed a similar overestimation of $z_{\operatorname{mix}}\left(\mathrm{O}_{2}\right)$ as the density and temperature criteria. By using the L06 criterion on our $\mathrm{O}_{2}$ profiles, we observed the opposite, with a tendency of underestimation of the $z_{\text {mix }}$ due to the presence of WW in the upper water column. However, the L06 criterion has the advantage of being independent of the actual value of the variable in question. This is also true for $z_{\text {mix }}\left(\mathrm{O}_{2}\right)$, which uses a relative difference of $0.5 \%$ independent of the actual $\mathrm{O}_{2}$ concentration.

The $95 \% \mathrm{O}_{2}$ saturation criterion proposed by Talley (1999) gives mostly lower $z_{\text {mix }}$ values than $z_{\text {mix }}\left(\mathrm{O}_{2}\right)$ as defined here. Talley's criterion was designed to establish deep winter mixed layers and therefore is not suitable for the detection of shallow summer mixed layers as encountered during summer and early autumn in the Bellingshausen Sea. In this and similar regions, the physical and biogeochemical processes would not appear to be comparable enough from place to place and time to time to allow using such an "absolute" horizon. Furthermore, in the coastal Southern Ocean,

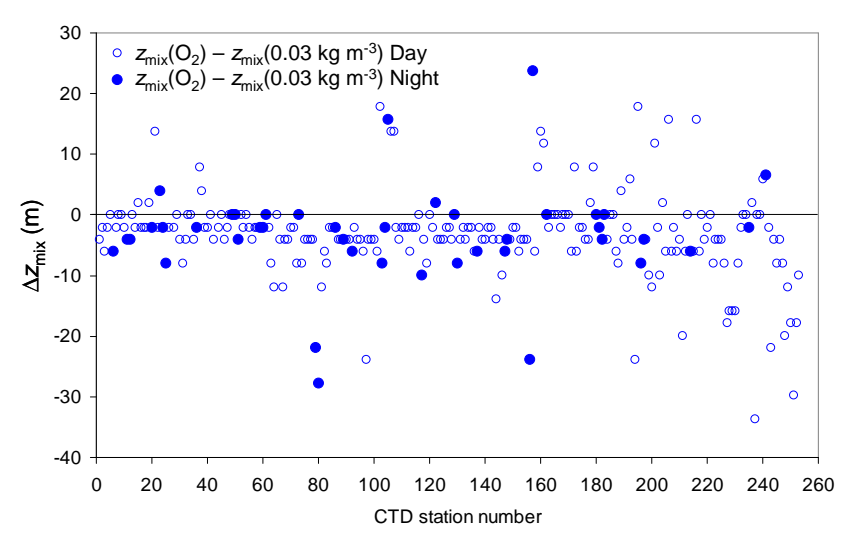

Fig. 6. Difference between $z_{\text {mix }}\left(\mathrm{O}_{2}\right)$ and $z_{\text {mix }}\left(0.03 \mathrm{~kg} \mathrm{~m}^{-3}\right)$ during day and night.

surface cold waters are normally in equilibrium or slightly undersaturated in $\mathrm{O}_{2}$ for most of the year (Garcia and Keeling, 2001).

The nighttime convection and overturning have a daily effect on the $z_{\operatorname{mix}}$ with higher values as the wind speed increases during the night. This effect might also yield a differential response of gas fluxes due to diurnal thermocline variations. From the total CTD profiles evaluated here, $17 \%$ (43 stations) were sampled during the period of darkness (about $5 \mathrm{~h}$; from 23:00 to 04:00 $\mathrm{h}$ local time). From the observations in Fig. 6, there is no clear difference between $z_{\text {mix }}$ during the night and day, using either $\mathrm{O}_{2}$ or the potential density criterion $\Delta \sigma_{\theta}=0.03 \mathrm{~kg} \mathrm{~m}^{-3}$. In order to evaluate in detail the effect of nighttime convection on $z_{\text {mix }}\left(\mathrm{O}_{2}\right)$, in situ measurements of the vertical profile of $\mathrm{O}_{2}$ in a daily time series at the same geographical location are needed. High variability due to diurnal effects has been investigated before for oxygen isotopes in dissolved water from Sagami Bay, Japan (Sarma et al., 2006). The distribution of oxygen isotopes was found to be strongly influenced by diurnal variability. This effect would also influence production calculations, but can be neglected for our study.

The accuracy of $z_{\text {mix }}$ defined using a threshold criterion depends on the resolution of the hydrographic parameter chosen for the $z_{\text {mix }}$ definition. Modern CTD observations 
provide sufficiently high resolution to resolve stratification in the upper water column. However, the coarser resolution of current climatologies and WOA data make them less suitable to establish $z_{\text {mix }}$. Furthermore, the low abundance of $\mathrm{O}_{2}$ profiles in Southern Ocean climatologies means that $z_{\text {mix }}$ obtained from these data collections are unreliable when compared to results based on CTD-O $\mathrm{O}_{2}$ profiles. The difference between $z_{\text {mix }}\left(\Delta \sigma_{\theta}\right)$ and $z_{\text {mix }}\left(\mathrm{O}_{2}\right)$ for CTD profiles and WOA05-profiles may often be due to the vertical resolution of the data and the interpolation method used to construct the temperature, salinity and $\mathrm{O}_{2}$ fields in WOA05.

We note that the suggested relative difference criterion may also be used with uncalibrated $\mathrm{O}_{2}$ profiles, provided that data affected by sensors noise or ship motion are removed first.

\section{Conclusions}

We propose to use $\mathrm{O}_{2}$ concentrations to define $z_{\text {mix }}$ $\left(z_{\text {mix }}\left(\mathrm{O}_{2}\right)\right)$ for gas exchange studies. In this way, $z_{\text {mix }}\left(\mathrm{O}_{2}\right)$ has the advantage of being directly related to a species of interest. Moreover, the relative nature of $z_{\text {mix }}\left(\mathrm{O}_{2}\right)$ criterion means that it may be applicable to other parts of the worlds' oceans, including during other times of the year. The proposed criterion is more sensitive to better reflect upper mixed layer air-sea dynamics and the influence of biological and physical processes, rather than criteria based on potential temperature or density, particularly in regions with weak vertical temperature and density gradients.

To define $z_{\text {mix }}\left(\mathrm{O}_{2}\right)$, we used CTD-O $\mathrm{O}_{2}$ profiles collected during late summer and autumn 2007 in the Bellingshausen Sea. $z_{\text {mix }}$ was well defined by the depth where the relative difference in $\mathrm{O}_{2}$ concentration to the $10 \mathrm{dbar}$ reference level exceeded $0.5 \%$. The criterion was validated by visual inspection, with $94 \%$ of the profiles in good agreement with the proposed criterion.

In coastal waters of the Southern Ocean, salinity stratification is a limiting factor for upper water dynamics due to the strong ice-melting water signal. Comparison of $z_{\text {mix }}\left(\mathrm{O}_{2}\right)$ with $z_{\text {mix }}$ based on potential density and temperature criteria showed best agreement for the $\Delta \sigma_{\theta}=0.03 \mathrm{~kg} \mathrm{~m}^{-3}$ criterion, either applied directly to the CTD profiles or based on the corresponding monthly climatology BM04. Thus, in the absence of $\mathrm{O}_{2}$ profiles, the $z_{\text {mix }}\left(0.03 \mathrm{~kg} \mathrm{~m}^{-3}\right)$ criterion might be used. Furthermore, in the absence of CTD stations at all, the BM04 climatology based on the same $\Delta \sigma_{\theta}$-criterion appears to be suitable for the determination of $z_{\text {mix }}$ in the Bellingshausen Sea.
Acknowledgements. The British Antarctic Survey (BAS) and the Natural Environment Research Council supported this project through grant CGS8/29. KCM thanks the National Council for Science and Technology (CONACyT), Mexico, for her $\mathrm{PhD}$ scholarship at the University of East Anglia. JK was also supported by a Royal Society Wolfson Research Merit Award (WM052632). Our thanks extend to the principal scientist, Deborah Shoosmith, and the other participants and crew of cruise JR165, as well as the leader of the ACES-FOCAS project, Adrian Jenkins. We are also grateful for the comments received from two anonymous reviewers and the editor that helped to improve the manuscript.

Edited by: M. Hoppema

\section{References}

Antonov, J. I., Locarnini, R. A., Boyer, T. P., Mishonov, A. V., and García, H. E.: Salinity, in: World Ocean Atlas, 2005, edited by: Levitus, S., NOAA Atlas NESDIS 62, U.S. Government Printing Office, Washington, D.C., 182, 2006.

Arrigo, K. R., van Dijken, G. L., and Bushinsky, S.: Primary production in the Southern Ocean, 1997-2006, J. Geophys. Res., 113, C08004, doi:10.1029/2007JC004551, 2008.

Brainerd, K. E., and Gregg, M. C.: Surface mixed and mixing layer depths, Deep-Sea Res., 42, 1177-1200, doi:10.1016/09670637(95)00068-H, 1995.

Cisewski, B., Strass, V. H., Losch, M., and Prandke, H.: Mixed layer analysis of a mesoscale eddy in the Antarctic Polar Front Zone, J. Geophys. Res., 113, C05017, doi:10.1029/2007JC004372, 2008.

de Boyer Montégut, C., Madec, G., Fisher, A. S., Lazar, A., and Iudicone, D.: Mixed layer depth over the global ocean: an examination of profile data and profile-based climatology, J. Geophys. Res., 109, C12003, doi:10.1029/2004JC002378, 2004.

de Boyer Montégut, C., Mignot, J., Lazar, A., and Cravatte, S.: Control of salinity on the mixed layer depth in the world ocean: 1. General description, J. Geophys. Res., 112, C06011, doi:10.1029/2006JC003953, 2007.

Dong, S., Sprintall, J., Gille, S. T., and Talley, L.: Southern Ocean mixed-layer depth from Argo float profiles, J. Geophys. Res., 113, C06013, doi:10.1029/2006JC004051, 2008.

Ducklow, H. W., Fraser, W., Karl, D. M., Quetin, L. B., Ross, R. M., Smith, R. C., Stammerjohn, S., Vernet, M., and Daniels, R. M.: Water-column processes in the West Antarctic Peninsula and the Ross Sea: Interannual variations and foodweb structure, DeepSea Res. Pt. II, 53, 834-852, doi:10.1016/j.dsr2.2006.02.009, 2006.

Fairall, C. W., Hare, J. E., Edson, J. B., and McGillis, W.: Parameterization and micrometeorological measurement of air-sea gas transfer, Bound.-Lay. Meteorol., 96, 63-105, doi:10.1023/A:1002662826020, 2000.

Garcia, H. E. and Keeling, R. F.: On the global oxygen anomaly and air-sea flux, J. Geophys. Res., 106, C12, 31155-31166, doi:10.1029/1999JC000200, 2001.

Garcia, H. E., Locarnini, R. A., Boyer, T. P., and Antonov, J. I.: Dissolved Oxygen, Apparent Oxygen Utilization and Oxygen Saturation, in: World Ocean Atlas, 2005, edited by: Levitus, 
S., NOAA Atlas NESDIS 63, U.S. Government Printing Office, Washington, D.C., 342 pp., 2006.

Gordon, A. L. and Huber, B. A.: Southern Ocean winter mixed layer, J. Geophys. Res., 95, C7, 11655-11672, doi:10.1029/JC095iC07p11655, 1990.

Holte, J. and Talley, L.: A new algorithm for finding mixed layer depths with applications to Argo data and Subantarctic Mode Water Formation, J. Atmos. Ocean. Tech., 29, 9, 1920-1939, doi:10.1175/2009JTECHO543.1, 2009.

Jenkins, A. and Jacobs, S. S.: Circulation and melting beneath George VI Ice Shelf, Antarctica, J. Geophys. Res., 113, C04013, doi:10.1029/2007JC004449, 2008.

Kaiser, J., Reuer, M. K., Barnett, B., and Bender, M. L.: Marine productivity estimates from continuous oxygen/argon ratio measurements by shipboard membrane inlet mass spectrometry, Geophys. Res. Lett., 32, L19605, doi:10.1029/2005GL023459, 2005.

Kara, A. B., Rochford, P. A., and Hurlburt, H. E.: Mixed layer depth variability over the global ocean, J. Geophys. Res., 108, C3, 3079, doi:3010.1029/2000JC000736, 2003.

Körtzinger, A., Send, U., Wallace, D. W. R., Karstensen, J., and DeGrandpre, M.: Seasonal cycle of $\mathrm{O}_{2}$ and $p \mathrm{CO}_{2}$ in the central Labrador Sea: Atmospheric, biological, and physical implications, Global Biogeochem. Cycles, 22, GB1014, doi:10.1029/2007GB003029, 2008.

Le Quéré, C., Aumont, O., Monfray, P., and Orr, J. C.: Propagation of climatic events on ocean stratification, marine biology, and $\mathrm{CO}_{2}$ : case studies over the 1979-1999 period, J. Geophys. Res., 108, 3375, doi:10.1029/2001JC000920, 2003.

Levitus, S.: Climatological atlas of the world ocean, Professional Paper 13, U.S. Government Printing Office, NOAA, Rockville, M.D., 190 pp., 1982.

Locarnini, R. A., Mishonov, A. V., Antonov, J. I., Boyer, T. P., and García, H. E.: Temperature, in: World Ocean Atlas, 2005, edited by: Levitus, S., NOAA Atlas NESDIS 61, U.S. Government Printing Office, Washington, D.C., 182, 2006.

Lorbacher, K., Dommenget, D., Niiler, P., and Köhl, A.: Ocean mixed layer depth: A subsurface proxy of oceanatmosphere variability, J. Geophys. Res., 111, C07010, doi:10.1029/2003JC002157, 2006.

Lukas, R. and Lindstrom, E.: The mixed layer of the western equatorial Pacific Ocean, J. Geophys. Res., 96, 3343-3357, 1991.

Monterey, G. I. and Levitus, S.: Seasonal variability of mixed layer depth for the world ocean, in: NOAA Atlas NESDIS 14, U.S. Government Printing Office, Washington, D.C., 96 pp., 1997.

Noh, Y. and Lee, W.: Mixed and mixing layer depths simulated by and OGCM, J. Oceanogr., 64, 217-225, doi:10.1007/s10872008-0017-1, 2008.
Park, Y., Charriaud, E., Ruiz Pino, D., and Jeandel, C.: Seasonal and interannual variability of the mixed layer properties and steric height at station KERFIX, southwest of Kerguelen, J. Mar. Syst., 17, 571-586, 1998.

Reuer, M. K., Barnett, B. A., Bender, M. L., Falkowski, P. G., and Hendricks, M. B.: New estimates of Southern Ocean biological production rates from $\mathrm{O}_{2} / \mathrm{Ar}$ ratios and the triple isotope composition of $\mathrm{O}_{2}$, Deep-Sea Res., 54, 951-974, doi:10.1016/j.dsr.2007.02.007, 2007.

Rintoul, S. R. and Trull, T. W.: Seasonal evolution of the mixed layer in the Subantarctic Zone south of Australia, J. Geophys. Res., 106, C12, 31447-31462, doi:10.1029/2000JC000329, 2001.

Sarma, V. V. S. S., Abe, O., Hinuma, A., and Saino, T.: Shortterm variation of triple oxygen isotopes and gross oxygen production in the Sagami Bay, central Japan, Limnol. Oceanogr., 51, 3, 1432-1442, doi:10.4319/lo.2006.51.3.1432, 2006.

Sea-Bird Electronics, I.: Application Note no. 64-3, Sea Bird Electronics 43 Dissolved oxygen (DO) sensor - hysteresis correction, Application Note no. 64-3, Sea-Bird Electronics, Inc., Sea-Bird Electronics, I., Bellevue, WA, 1-7, 2010.

Smith, R. C., Martinson, D. G., Stammerjohn, S. E., Iannuzzi, R. A., and Ireson, K.: Bellingshausen and western Antarctic Peninsula region: Pigment biomass and sea-ice spatial/temporal distributions and interannual variabilty, Deep-Sea Res. Pt. II, 55, 18-19, 1949-1963, doi:10.1016/j.dsr2.2008.04.027, 2008.

Talley, L.: Some aspects of ocean heat transport by the shallow, intermediate and deep overturning circulations, in: Mechanisms of Global Climate Change at Millennial Time Scales, edited by: Clark, P. U., Webb, R. S., and Keigwin, L. D., Geophysical Monograph, American Geophysical Union, Washington, D.C., 1999.

Thomson, R. E. and Fine, I. V.: Estimating mixed layer depth from oceanic profile data, J. Atmos. Ocean. Tech., 20, 319-329, http://dx.doi.org/10.1175/15200426(2003)020<0319:EMLDFO>2.0.CO;2, 2003.

Verdy, A., Dutkiewicz, S., Follows, M. J., Marshall, J., and Czaja, A.: Carbon dioxide and oxygen fluxes in the Southern Ocean: Mechanisms of interannual variability, Global Biogeochem. Cycles, 21, GB2020, doi:10.1029/2006GB002916, 2007.

Williams, G. D., Nicol, S., Raymond, B., and Meiners, K.: Summertime mixed layer development in the marginal sea ice zone off the Mawson coast, East Antarctica, Deep-Sea Res. Pt. II, 55, 365-376, doi:10.1016/j.dsr2.2007.11.007, 2008.

Zawada, D. G., Roland, J., Zaneveld, V., and Boss, E.: A comparison of hydrographically and optically derived mixed layer depths, J. Geophys. Res., 110, C11001, doi:10.1029/2004JC002417, 2005. 